Ramaz Kurdadze, Maia Lomia, Ketevan Margiani

Ivane Javakhishvili Tbilisi State University

\title{
Conditional-Resultative Hypotactic Constructions from the Viewpoint of Evidentiality on the Empirical Material of the Kartvelian Languages ${ }^{1}$
}

\begin{abstract}
Evidentiality is a universal category, the study of which should be carried out on the grammatical (morphological and syntactic) and lexical levels. The paper analyzes conditional-resultative hypotactic constructions from the viewpoint of evidentiality. Conditional-resultative hypotactic constructions consist of two components - main and subordinate clauses; The condition is given in the subordinate clause, the predicate of which represents the action which serves as a precondition for the fulfillment of the second action. The condition is followed by the result, which is given in the main clause and takes place if the corresponding condition is fulfilled.

Such hypotactic construction is based on background knowledge, as the action described in the conditional-resultative sentence implies logical inter-relation between the clauses. The following questions should be answered in this regard: What are the characteristic features of these constructions from the viewpoint of evidentiality? Does the logical relation between the main and subordinate clauses represent a source of information which serves as a basis for evidentiality?

Based on the analysis of the empirical material, it can be concluded that hypotactic constructions are evidential if conclusions or assumptions are drawn on the basis of logical conditional-resultative relations (and not perceptive facts), as well as the background knowledge/experience of the speaker.

Hypotactic constructions are not evidential unless the logical relation between conditional-resultative clauses implies the above-mentioned nuances, and if only a certain fact, result or appeal is represented.

The paper also focuses on the data of other Kartvelian languages and reveals the typology of the Kartvelian languages with regard to the issue under analysis.
\end{abstract}

Key words: Evidentiality, hypotactic constructions, Kartvelian languages.

\footnotetext{
${ }^{1}$ The paper has been implemented within the framework of the scientific project: „The Category of Evidentiality in the Kartvelian Languages“(\#217_300); financed by Shota Rustaveli National Scientific Foundation (Georgia).
} 
It is well known that evidentiality is a universal category which is studied on the grammatical (morphological and syntactic) and lexical levels. The given paper analyzes conditional-resultative hypotactic constructions from the viewpoint of evidentliaty.

Fulfillment or non-fulfillment of the condition given in the conditional subordinate clause defines the result expressed by the main clause. Therefore, the condition refers not to one of the members, but to the entire main clause. The conceptual relation between the conditional-resultative components is as follows: if a certain condition is fulfilled, the result will be achieved (Shanidze 1980, 208209, 222; Kvachadze 1988 390-395).

In the Kartvelian languages ${ }^{2}$, evidentiality is expressed morphologically and semantically. Diverse types of evidentiality are revealed differently on various language levels. For instance, in Georgian, evidentiality is revealed by means of the future tense, conditional, perfect verb forms, lexical means, indirect speech markers, evidential particles etc. (Topadze 2011).

As it was mentioned above, the aim of the given paper is to discuss complex sentences from the viewpoint of

\footnotetext{
2 The Kartvelian (resp. South Caucasian) group embraces four languages, out of which Georgian is a written literary language, whereas Megrelian, Svan and Laz are non-literary, non-written languages.
}

evidentiality. Our interest towards the issue is caused by the necessity to find out whether the logical relationship between the components of such constructions is perceived as a source of information that forms grounds for evidentiality.

In order to answer the above question, initially we carry out a more or less detailed analysis of the semantic groups of conditional-resultative

hypotactic constructions based on the empirical data of the literary Georgian language.

Despite the abundance of the semantic groups, two contrastive theses can be distinguished, in one case, based on the background knowledge and experience of the speaker (I), and, in the other case, based on real facts (II). Thesis I embraces two semantic groups: a) evidential, b) of epistemic modality, as, on the basis of logical relation between conditional-resultative moods, the assumption is made based on the background knowledge/experience of the speaker (but not on perceptive facts). Thesis II embraces all the rest: order, offer/urge, declaration/promise, rhetorical question, exclamation/threat or statement of a certain fact (other similar groups can also be distinguished). In this case, the logical relation between conditional-resultative moods is based not on the background knowledge but on real facts. 
As expected, such division proves the close links between evidentiality and epistemic modality. It should be mentioned that the subordinate clause of every conditional-resultative complex sentence (resp. condition) is of epistemic modality, whereas the main clauses (resp. result) are diverse. The final semantics of the construction is defined by the resultative clause. Hence, the question: how can the unity of such closely-linked components (as condition and result) yield such semantic diversity? In order to answer this question, the components should be analyzed separately and the rules of their relationships should be identified:

\section{I.}

\section{a) Evidential}

The subordinate clause (resp.condition) is epistemic: the main clause (resp.result) is evidential.

The above relationship is conditioned by the following fact: when the fulfillment of a certain condition is sufficient for the absolute result, the subordinate clause restricts the action denoted by the verbpredicate of the main clause, and the action is performed according to the condition given in the subordinate clause. Therefore, there is no room for assumption or doubt. Hence, the main clause is not epistemic. The semantics of the entire construction is not epistemic either. It is evidential:

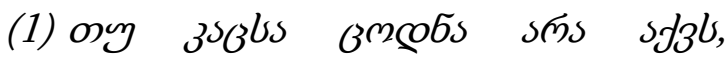

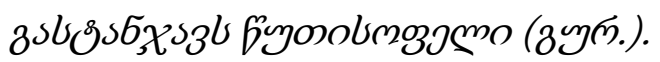
tu kacsa codna ara akvs, gasțanžavs çutisopeli .

"if a man has no knowledge, he will suffer in this world" (Guramishvili) (Kvachadze 1988, 392).

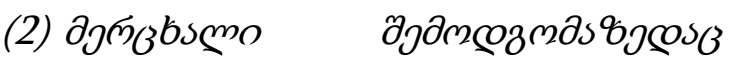

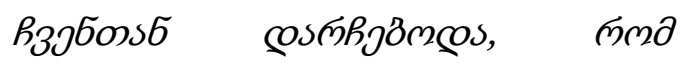

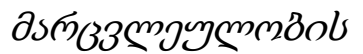

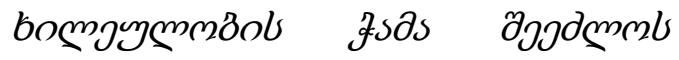
(zmz., 119).

mercxali šemodgomazedac ćventan darcieboda, rom marcvleulobis da xileulobis čama šeezlos.

"The swallow would stay with us even in autumn, if it could get grain and fruit" (Gogebashvili, 119) (Kvachadze 1988, 393).

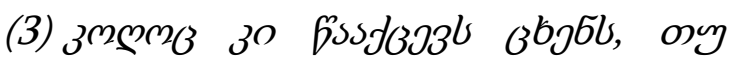

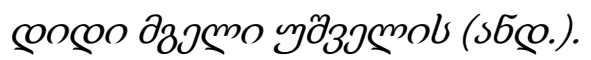

kojoc ki çaakcevs cxens, tu didi mgeli ušvelis.

"Even a mosquito can beat a horse, if it is assisted by a large wolf $f^{\prime \prime}$ (proverb) (Kvachadze 1988, 390).

\section{b) Epistemic modality}

The subordinate clause (resp. condition) is epistemic; the main clause (resp. result) is also epistemic. 
The above relationship is conditioned by the following fact: if the fulfillment of a certain condition is insufficient for achieving the absolute result, and additional condition/environment is required, the subordinate clause allows the epistemic nature of the main clause. Therefore, the main clause contains organic evidentialepistemic verb forms or particles that make the main clause epistemic. Hence, the semantics of the entire construction is epistemic:

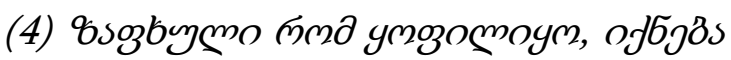

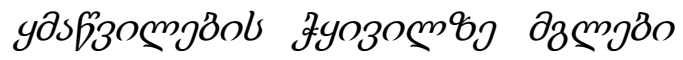

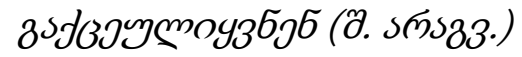

zapxuli rom qopiligo, ikneba qmaçvilebis čquivilze mglebi gakceuliqvnen.

"if it had been summer, the wolves would have run away on hearing the boys' shouting" (Shio Aragvispireli) (Kiziria 1974, 259).

\section{Neither evidential, nor epistemic}

The subordinate clause (resp. condition) is epistemic, whereas the main clause (resp. result) is neither evidential nor epistemic.

Such relationship is conditioned by the following fact:

when, according to the logical relation between conditional-resultative moods, the conclusion is drawn based on real facts, the resultative sentence is neither evidential nor epistemic. It is of totally different semantics, and may express order, urge/offer, declaration/promise, rhetorical question, exclamation/threat or a certain fact. The epistemic content of the subordinate clause simply serves to form a conditionalresultative sentence.

\section{Order:}

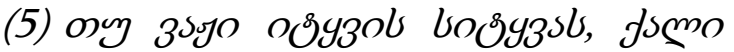

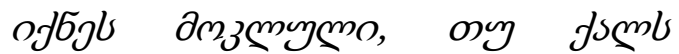

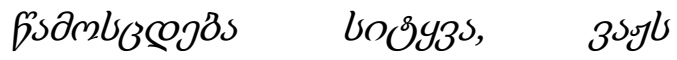
дмวзЗวоми олзо! (ммполу., 2, 328) tu važi ițvis sitgvas, kali iknes mokluli, tu kals çamoscdeba sițqua, važs moekvetos tavi!

"if the boy utters a word, the girl will be killed; and if the girl utters a word, the boy will be beheaded" (Lortkipanidze, 2, 328) (Kvachadze 1988, 392).

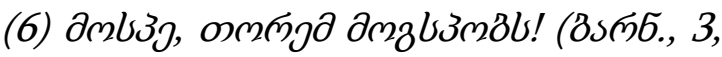
58).

mospe, torem mogspobs.

"If you don't eliminate him, he will eliminate you" (Barnovi, 3, 58) (Kvachadze 1988, 394).

\section{Urge/offer:}

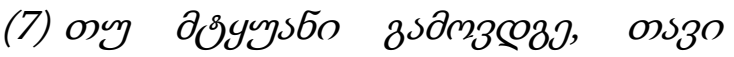

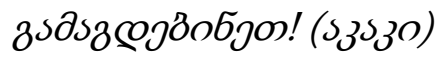


tu mțuai gamovdge, tavi gamagdebinet!

"If I am lying, cut my head off!" (Akaki Tsereteli) (Kiziria 1974, 259).

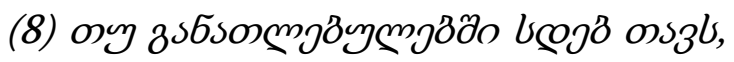

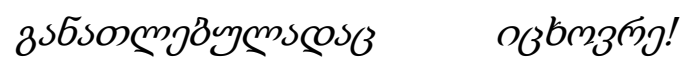
(Вงळ6., 1, 321)

tu ganatlebulebři sdeb tavs, ganatlebuladac icxovre!

"If you keep proving that you are educated, live like an educated person!" (Barnov, 1, 321) (Kvachadze 1988, 392).

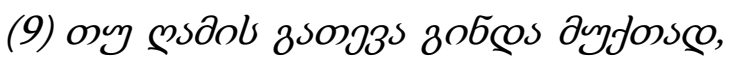

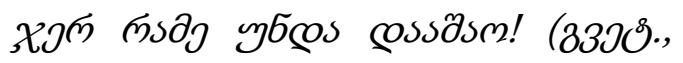
365)

tu ramis gateva ginda muktad, 亏̌er rame unda daašao!

"If you want a free shelter, you should commit a crime!" (Gvetadze, 365) (Kvachadze 1988, 392).

\section{Declaration/promise:}

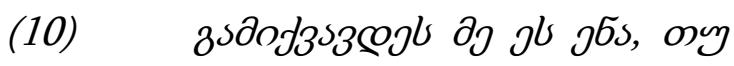

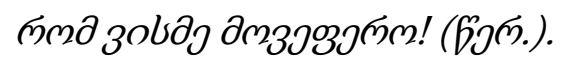

gamikvavdes me es ena, tu rom visme movepero!

"Let my tongue turn into stone if I flatter anyone!" (Tsereteli) (Kvachadze 1988, 393).

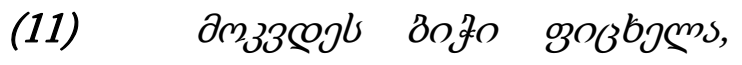

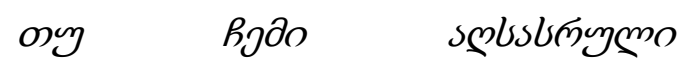

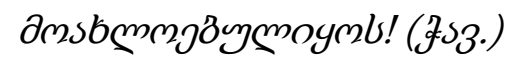

mokvvdes biči picxela, tu cemi aүsasruli moaxloebuligos.

"May I die, if my end is near" (Chavchavadze) (Kvachadze 1988, 392).

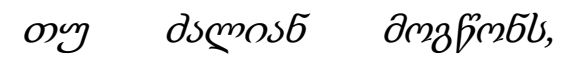

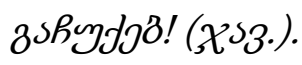

tu zalian mogçons, gacukeb!

"If you like it so much, I will give it to you as a present" (Javakhishvili, 2, 577) (Kvachadze 1998, 392).

\section{Rhetorical question:}

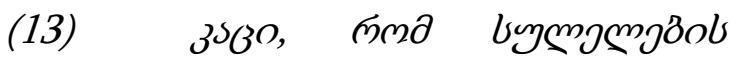

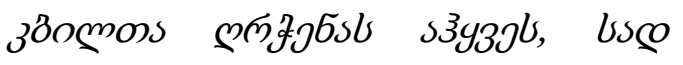
653ง?! (\$53., 447)

kaci rom sulelebis kbilta rrčenas ahqves, sad çava?!

"If a man follows the advice of fools, what will be his future?!" (Chavchavadze, 447) (Kvachadze 1988, 393).

(14) оулзо lsbeso

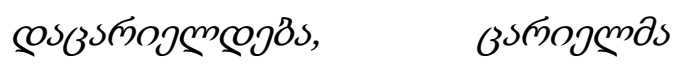

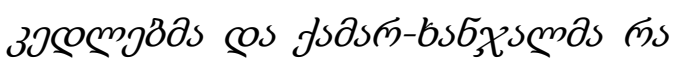

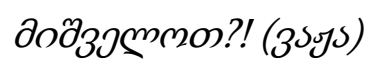

tuki saxli dacarieldeba, carielma kedlebma da kamar-xanǰalma ra mišvelot?!

"If the house gets empty, what is the use of empty walls or the weapons?!" (Vazha-Pshavela) (Kvachadze 1988, 392). 


\section{Exclamation/threat:}

oуy

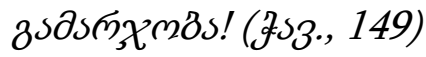

tu moqvare xar, maš gamař̌oba!

"If you have come as a friend, you are welcome!" (Chavchavadze, 149) (Kvachadze 1988, 395).

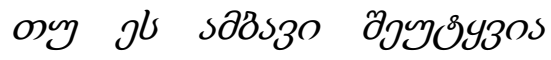

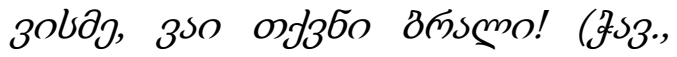
365)

tu es ambavi šeuṭvia visme, vai tkveni brali!

"If you tell this to anyone, blame yourself for what happens to you!" (Chavchavadze, 365) (Kvachadze 1988, 395). 3so, ony aszol zsॅ⿵дsбo uofybs的 zszo comol

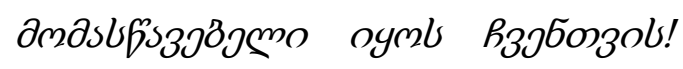
(3)ळ6., 3, 70)

vai, tu magis garegani siçqnare šavi

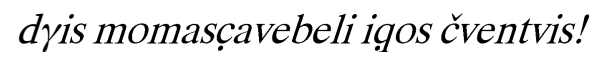

"What if his seeming peacefulness is a sign of something terrible" (Barnovi, 3, 70) (Kvachadze 1988, 395).

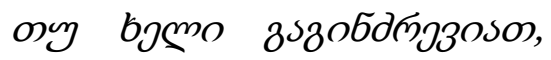

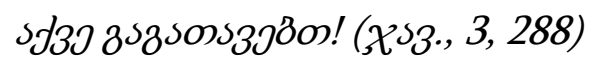
tu xeli gaginzreviat, akve gagatavebt! "If you move, I will kill you at once!" (Javakhishvili, 3, 288) (Kvachadze 1988, 391).

\section{Statement of a certain fact:}

(19)

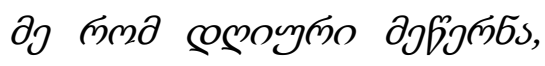

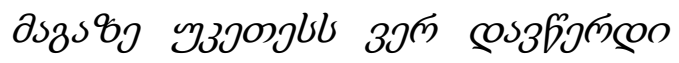
(X33., 3, 395)

me rom dyiuri meçerna, magaze uketess ver davçerdi.

"If I had written a diary, I could not have done better" (Javakhishvili, 3, 395) (Kvachadze 1988, 393);

(20) ju зәоомо cos zмболпо

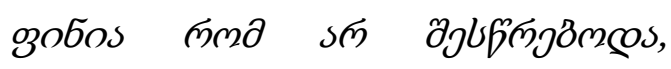

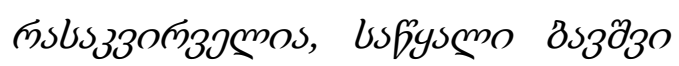

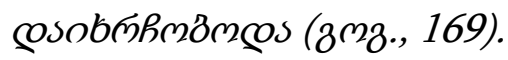

es ketili da gonieri pinia rom ar šesçreboda, rasakvirvelia, saçqali bavši daixrčoboda.

"If that kind and clever dog hadn't been nearby, the poor child would have been drawned" (Gogebashvili, 169) (Kvachadze 1988, 393).

In order to draw a complete picture of the typology of the Kartvelin languages, the data of other Kartvelian languages should be analyzed. With this aim, the empirical data of Megrelian, Laz and Svan languages has been obtained from the field work materials. It should be noted that Kartvelian languages reveal typological similarity from the viewpoint of semantic grouping of conditional-resultative constructions. This similarity is especially obvious with regard 
to the groups expressing evidentiality and epistemic modality. Other semantic groups distinguished in Georgian are less productive in non-written Kartvelian languages.

\section{Evidential:}

\section{Megrelian:}

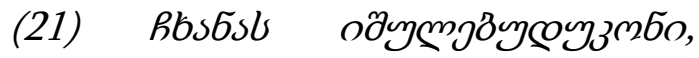
ojJos6masl as6songбroy.

Čxanas išuldebudukoni, tekinobas ganatendu.

\section{Laz:}

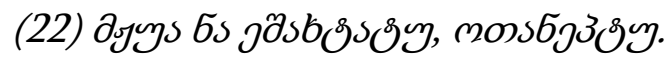
mžua na ešaxțațu, otanepțtu.

\section{Svan:}

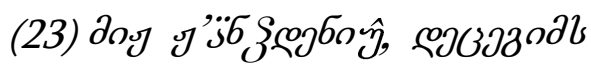
Jง6งณ3.

miž žänqdeniw, decegims kanarha.

"If the sun rose, it would light the area“.

\section{Epistemic modality:}

\section{Megrelian:}

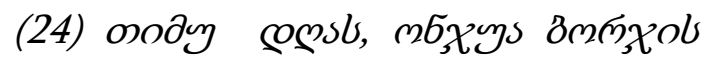

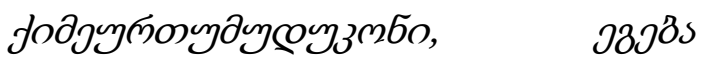
уодуһузм зопмдs.

timu dyas, onžua boržis kimeurtumuduḳoni, egeba kimečuko piroba.

Laz:

(25) ja copsl mozxol

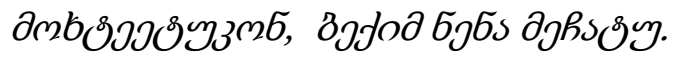
em dyas xolo limy̌is moxṭeețkonon, bekim nena mečațu.
"If he/she had come on the same evening, he/she might have given a promise".

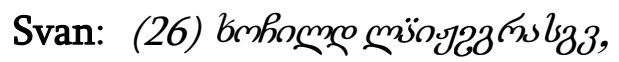

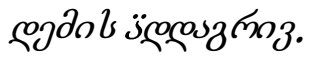
xočild läjžograsgw, demis äddagriw.

"If he/she had got better medical treatment, he/she might not have died".

The situation regarding the relationships between the components of the main and subordinate clauses is the same in all the Kartvelian languages.

- However, several facts should be mentioned, even though they do not change the entire picture of the typology of Kartvelian languages:

1. In Megrelian, there are modalized (epistemic) verb forms of organic formation, although they do not take part in the formation of conditional-resultative constructions.

2. Modalized (epistemic) verb forms are also found in the Svan language. Unlike Megrelian, in the Svan language, conditional-resultative constructions are expressed by such verb forms. Moreover, the expressive power of such verb forms is so strong that no conjunctions are needed to join the conditional-resultative components in the hypotactic constructions (see examples (23), (26)). 


\section{References}

Kvachadze 1988 - Kvachadze L., Syntax of the Contemporary Georgian Language, Publishing House "Ganatleba”, Tbilisi, 1988 (in Georgian);

Lomia - 2005 Lomia M., Issues of Hypotaxis in Megrelian, Publishing House "Universiali”, Tbilisi, 2015 (in Georgian);

Margiani 2012 - Margiani K., The Category of Evidenciality in the Svan Language, Publishing House, "Global-printi+", Tbilisi, 2012 (in Georgian);

Shanidze 1973 - Shanidze A., The Basics of the Grammar of the Georgian Language, collected works in 12 volumes, colume \# III, Tbilisi University Press, 1980 (in Georgian);

Topadze 2011 - Manana Topadze Gäumann, The Expression of Evidentiality between Lexicon and Grammar. A Case Study from Georgian, LINGVUSTIC DISCOVERY, DARTMOUTH COLLEGE, volume 9, Issue 2, 2011; url: http://journals.dartmouth.edu/cgibin/WebObjects/ Journals.woa/1/xmlpage/1/article/392.

\section{Sources:}

Field work materials obtained in Svan, Megrelian and laz villages of Georgia in 2017-2018 (in Georgian);

Kiziria A., The Georgian Language, Practicum, Publishing House "Ganatleba", Tbilisi, 1974 (in Georgian);

Kvachadze L., Syntax of the Contemporary Georgian Language, Publishing House "Ganatleba”, Tbilisi, 1988 (in Georgian). 